\title{
Potential of Moringa (Moringa oleifera) Leaf Extract to Inhibit the Growth of Pathogenic Bacteria Edwardsiella tarda
}

\author{
Farid Mukhtar Riyadi ${ }^{1 *}$, Arief Prajitno ${ }^{2}$, Muhamad Fadjar ${ }^{2}$, Arif Syaifurrisal ${ }^{1}$ and \\ Annisa Isti Fauziyyah ${ }^{1}$ \\ ${ }^{1}$ Magister Study Program of Aquaculture, Faculty of Fisheries and Marine Sciences, Brawijaya \\ University, Jl. Veteran, Ketawanggede, Lowokwaru, Malang 65145, Indonesia \\ ${ }^{2}$ Aquaculture Study Program, Faculty of Fisheries and Marine Sciences, Brawijaya University, Jl. \\ Veteran, Ketawanggede, Lowokwaru, Malang 65145, Indonesia
}

*Correspondence :

faridmukhtar97@gmail.com

Received : 2021-01-27

Accepted : 2021-07-14

Keywords :

Antibacterial activity, Moringa leaf extract, Inhibition zone, E. tarda

\begin{abstract}
This study analyzed the antibacterial activity of Moringa oliefera leaf extract against the growth of Edwardsiella tarda bacteria. This study aims to determine the antibacterial activity of Moringa leaf extract ( $M$. oliefera) against the growth of E. tarda bacteria. Inhibition testing is done by diffusion method (disc test). The disc test used five variations of concentration of $75 \mathrm{mg} / \mathrm{L}, 150 \mathrm{mg} / \mathrm{L}, 225 \mathrm{mg} / \mathrm{L}, 300 \mathrm{mg} / \mathrm{L}$, and $375 \mathrm{mg} / \mathrm{L}$ on TSA (Tryptone Soya Agar) media and incubated for $2 \times 24$ hours. As a positive control, an antibiotic in the form of chloramphenicol was used. ( $5 \mathrm{mg} / \mathrm{L}$ ) Moreover, distilled water was used as a negative control. Moringa leaf extract contains natural active compounds, bacteriostatic antibacterial, due to decreased bacterial growth after 48 hours of incubation. The highest inhibition diameter of $E$. tarda was $12.95 \mathrm{~mm}$ at a concentration of $375 \mathrm{mg} / \mathrm{L}$ after 24 hours incubation and decreased by $11.02 \mathrm{~mm}$ after 48 hours incubation. The highest inhibitory effectiveness was at a concentration of $375 \mathrm{mg} / \mathrm{L}$ with an effectiveness of $58.8 \%$, while the effectiveness of the decrease was $48.1 \%$ after 48 hours of incubation.
\end{abstract}

\section{INTRODUCTION}

The problem that is often faced by fish farming communities is disease attacks. With a disease attack, cultured fish experience high mortality or mortality in a short time, resulting in a large number of fish farmers experiencing considerable economic losses (Ashari et al., 2014).

Fish diseases that often attack aquaculture activities are from bacteria, one of which is E. tarda. According to Narwiyani and Kurniasih (2011), the factors influencing E. tarda infection are fish stress, primarily due to high stocking density, poor water quality conditions, and high content organic matter. Horizontal disease transmission of $E$. tarda bacteria is contact between one host and another or through the water. The external symptoms of fish attacked by edwardsiellosis in mild infections only show small wounds (Indriasari et al., 2020).

So far, to minimize deaths in $E$. tarda attacks by using chemicals or antibiotics classified as safe, and their use is following government regulations (A'yunin et al., 2019). However, the continuous use of chemicals can cause 
new problems. Namely, it can increase environmental pollution, accumulate antibiotic residues in fish tissue, affect its growth and resistance to drugs (Maqsood et al., 2009; Kadlec et al., 2011). Therefore, other alternative materials are needed as candidates for antibiotic replacement drugs from natural ingredients, including Moringa leaves (Moringa oliefera).

Moringa plants are used for leaves, seeds, flowers, pods (fruit), bark, and roots with several active antibacterial compounds. According to Pandey et al. (2012), Moringa leaves have secondary metabolite compounds such as flavonoids, alkaloids, phenols, and tannins, inhibiting bacterial activity. Research on Moringa leaf extract as antibacterial from various sources has been done, so it is necessary to research to determine Moringa leaf extract antibacterial against $E$. tarda, which is the cause of disease in aquaculture.

The purpose of this study was to determine the in vitro antimicrobial activity of Moringa leaf extract against $E$. tarda bacteria.

\section{METHODOLOGY}

\section{Place and Time}

This research was conducted from December 2020 to January 2021 at the Fish Health Disease Laboratory of Faculty of Fisheries and Marine Sciences, Brawijaya University, Malang.

\section{Research Materials}

The tools used in this research were Erlenmeyer, rotary vacuum evaporator, vortex mixer, spatula, tray, funnel, digital scales, analytical scales, film bottles, test tubes, test tube racks, petri dishes, ose needles, suction balls, Bunsen, hot plate, spectrophotometer, drop pipette, sprayer bottle, laminar airflow (LAF), oven, refrigerator, incubator, measuring cup, autoclave, beaker glass, aquarium, aerator, aeration stone, aquarium heater, section set, and syringe.

The materials used in the extraction activity were Moringa leaves (M. oliefera) obtained in the Dinoyo area, Malang, East Java. The Solvent for maceration is ethanol with pro-analysis quality (PA), filter paper with the trademark Whatman No. 42, aluminum foil and plastic warp, dimethyl sulfoxide (DMSO), and hydro bath. For bacterial culture and antibacterial inhibition test, the materials used were E. tarda bacteria obtained from the Fish Quarantine and Inspection Agency, Jakarta, culture media, namely Tryptic Soy Agar (TSA) Merck, Tryptone Soya Broth (TSB) Merck, aquades, alcohol, disc paper with a diameter of 6 $\mathrm{mm}$.

\section{Research Design}

The method used in this research was experimental. The research design in this study was a completely randomized design (CRD). The treatments used in this study were five treatments with different doses, positive control, negative control, and three repetitions.

\section{Work Procedure \\ Preparation of Moringa Leaf Extract (M. oliefera)}

Moringa leaves were collected and cleaned. Then, Moringa leaves were dried by being aerated in the room until dry, then milled and sieved to obtain a fine powder (Susanty et al., 2019). A total of $100 \mathrm{~g}$ Moringa leaf powder was macerated using Simplicia soaked in $1000 \mathrm{ml}$ of ethanol solvent (ratio 1:10) for $2 \times 24$ hours at room temperature $\pm 25-28{ }^{\circ} \mathrm{C}$. The extract was filtered using filter paper then evaporated with a rotary vacuum evaporator at a temperature of $35-40{ }^{\circ} \mathrm{C}$, and the yield was calculated (Hayati et al., 2012; Wardhani et al., 2018).

\section{Phytochemical Screening}

Phytochemical analysis was carried out according to the Harborne method (Putra et al., 2016). The aim is to observe the active compounds in the crude extract. The compounds analyzed included: flavonoids, alkaloids, phenolics, steroids, 
tannins, and saponins with a density of $10^{4}$ individual $/ \mathrm{mL}$.

\section{Preparation of Bacteria}

E. tarda isolate from the Fish Quarantine and Inspection Agency (BUSKIPM) Jakarta. These bacteria were stored in Trypticase Soy Agar (TSA) medium at $\pm 4{ }^{\circ} \mathrm{C}$ and sub-culture Trypticase Soy Broth (TSB) overnight before use.

\section{Antibacterial Activity Test}

The test for the antibacterial activity of Moringa leaf extract against pathogenic bacteria E. tarda using the diffusion method was carried out with the disc test. According to Fitriana et al. (2019), it was used to determine the test microbes' sensitivity to antimicrobial agents. The dose of Moringa leaf extract tested consisted of 5 concentrations $(75 \mathrm{mg} / \mathrm{L}$, $150 \mathrm{mg} / \mathrm{L}, 225 \mathrm{mg} / \mathrm{L}, 300 \mathrm{mg} / \mathrm{L}$ and 375 $\mathrm{mg} / \mathrm{L}$ ) and 2 controls (positive and negative). Chloramphenicol at a concentration of $5 \mathrm{mg} / \mathrm{L}$ was used as a positive control. Measurement of the clear zone from each dose of $M$. oliefera leaf extract using a digital caliper in millimeters units (mm).

\section{Scanning Electron Microscope (SEM)}

SEM observations are intended to determine the damage to the morphology of bacterial cells due to the administration of extracts containing active ingredients (Hariati et al., 2018). Preparation of E. tarda preparations was carried out with 2 treatments. The first treatment of $E$. tarda was normal, the second treatment of $E$. tarda was given Moringa leaf extract with a dose of $400 \mathrm{ppm}$. Then the two preparations were ready to be observed using SEM (Scanning Electron Microscope).

Analysis of damage to E. tarda bacteria was carried out by comparing photos from SEM observations between normal conditions and bacteria given Moringa leaf extract and seeing the picture of the damage to the bacterial cell wall. Based on the results of the damage analysis, it will be continued in the next stage.

\section{Data Analysis}

Phytochemical data analysis was carried out by observing the extract solution's color change in the phytochemical test. Data measurements were performed during the 24 and 48 hour incubation period for the disc test. The data obtained from the measurement results are tabulated and analyzed by measuring the disc test's resistance zone's diameter. The calculation of the extract inhibition effectiveness is calculated based on the equation (Hamzah, 2019).

$\mathrm{E}=\frac{\mathrm{D}}{\mathrm{Da}} \times 100 \%$

Where:

$\mathrm{E} \quad=$ effectiveness of inhibition (\%)

$\mathrm{D}=$ diameter of plant material extract inhibition zone (mm)

$\mathrm{Da}=$ diameter of antibiotic inhibition zone (mm)

\section{RESULTS AND DISCUSSION The Yield of Moringa Leaf Extract}

The yield obtained from the maceration of Moringa leaf extract with $96 \%$ ethanol solvent is presented in table 1.

Table 1. Yield Moringa leaf extract.

\begin{tabular}{cccccc}
\hline Solvent Type & $\begin{array}{c}\text { Total } \\
\text { Solvent }(\mathrm{ml})\end{array}$ & $\begin{array}{c}\text { Sample } \\
\text { Weight }(\mathrm{g})\end{array}$ & $\begin{array}{c}\text { Extract } \\
\text { Weight }(\mathrm{g})\end{array}$ & Yield (\%) & FHI requirements \\
\hline Ethanol 96\% & 1000 & 100 & 9,51 & $9,51 \%$ & Not less $9.2 \%$ \\
\hline
\end{tabular}

The yield of $96 \%$ ethanol extract from Moringa oleifera leaves above is obtained from the final weight after extraction is complete compared to the number of simplicial used at the time of extraction (Alegantina et al., 2013). The 
results from Table 1 indicate that the yield value obtained was $9.51 \%$. These results meet the Indonesian Herbal Pharmacopoeia requirements; namely, the yield is not less than $9.2 \%$. Determination of yield aims to determine the approximate amount of Simplicia needed to make a certain amount of thick extract (Kartikasari et al., 2014).

\section{Phytochemical Screening}

$M$. oleifera L. leaf extract's phytochemical test results showed alkaloids, flavonoids, triterpenoids, and tannins, as in Table 2.

Table 2. Phytochemical test results on M. oliefera L. leaves.

\begin{tabular}{lll}
\hline Compound Identification & Characteristics & Result \\
\hline Flavonoid & Orange, Brick Red, Pink, Dark Red & $(+)$ Positive \\
Alkaloid & & \\
Meyer & White sediment & $(+)$ Positive \\
Dragendorff & Orange sediment & $(+)$ Positive \\
Bouchardat & Brown sediment & $(-)$ Negative \\
Tannin & Blackish Brown, Blackish Blue & $(+)$ Positive \\
Terpenoid & & \\
Steroid & Bluish Green & $(-)$ Negative \\
Triterpenoid & Orange, Brownish Orange & $(+)$ Positive \\
Saponin & Permanent Foam & $(-)$ Negative \\
\hline
\end{tabular}

Note: $(+)=$ there is a chemical content, $(-)=$ there is no chemical content.

Meanwhile, alkaloid and terpenoid compounds were not found (Table 1). Alkaloids, flavonoids, triterpenoids, and tannins are active compounds with various functions, including antibacterial activity. According to Widowati et al. (2014), the mechanism for reducing microorganisms using Moringa leaf extract is caused by antibacterial phytochemicals, namely flavonoids and tannins saponins, and polyphenols with bacterial inhibition mechanisms. The mechanism of action is with antibacterial compounds, including inhibiting cell wall synthesis, inhibiting the integrity of bacterial cell wall permeability, inhibiting enzyme action, and inhibiting the synthesis of nucleic acids and proteins. Naturally, these active compounds are present in plants as a mechanism for protecting themselves from disease and damage from the external environment (Kenconojati and Rukman, 2019).

\section{Antibacterial Activity Test}

The antibacterial activity test results showed that Moringa leaf extract could inhibit bacterial growth. Inhibition of bacterial growth based on extract dosage. The clear zone indicates Moringa's leaf extract's ability to inhibit E. tarda bacteria's growth. The clear zone measurements around the disc paper were observed at 24 and 48 hours after incubation. The measurements of the clear zone around the disc paper in 24 hours are presented in Table 3.

Table 3. The results of the 24-hour Moringa (M. oleifera) leaf extract disc test.

\begin{tabular}{ccc}
\hline $\begin{array}{c}\text { Concentration } \\
(\mathrm{mg} / \mathrm{L})\end{array}$ & $\begin{array}{c}\text { Average Inhibition Zone } \\
\text { Diameter }(\mathrm{mm})\end{array}$ & $\begin{array}{c}\text { Inhibition Zone Response } \\
\text { Qualifications }\end{array}$ \\
\hline $\mathrm{K}-$ & $0 \pm 0.00^{\mathrm{a}}$ & Weak \\
75 & $4,41 \pm 0.27^{\mathrm{b}}$ & Moderate \\
150 & $5,28 \pm 0.58^{\mathrm{c}}$ & Moderate \\
225 & $6,36 \pm 0.45^{\mathrm{d}}$ & Moderate \\
300 & $6,67 \pm 0.21^{\mathrm{d}}$ & Moderate \\
375 & $7,30 \pm 0.21^{\mathrm{e}}$ & Strong \\
$\mathrm{K}+$ & $15,99 \pm 0.10^{\mathrm{f}}$ & Very Strong \\
\hline
\end{tabular}


Note: $\quad$ Classification of inhibition zone diameter, weak $=3 \mathrm{~mm}$, moderate $3-6 \mathrm{~mm}$ and strong $>6 \mathrm{~mm}$ (Pan et al., 2009).

The results of measuring the inhibition zone diameter at all doses with time intervals of 24 indicated that the number of extract doses given could increase the diameter inhibition zone. At extract concentrations of $75 \mathrm{mg} / \mathrm{L}, 150$ $\mathrm{mg} / \mathrm{L}, 225 \mathrm{~m} / \mathrm{L}$, and $300 \mathrm{~m} / \mathrm{L}$ included in the moderate category with the mean diameter of the inhibition zone 4,41, 5,28, 6,36 , and 6,67 . The extract with a strong inhibition zone was $375 \mathrm{mg} / \mathrm{L}$, with an average diameter of $7,30 \mathrm{~mm}$. This is following the opinion of Pan et al. (2009) in determining the inhibition zone category is the result of the diameter of the inhibition zone minus the diameter of the $6 \mathrm{~mm}$ paper disc and the classification of bacterial inhibition zones, namely those with a diameter of $0-3 \mathrm{~mm}$ is in the weak category, $3-6 \mathrm{~mm}$ is in the medium category and $>6 \mathrm{~mm}$ is classified as strong inhibition zones.

The results showed that the higher the concentration used, the greater the resistance zone formed. Flavonoid compounds are phenolic compounds that can cause protein denaturation and damage cell walls. The inhibition of the growth of bacterial colonies is thought to be caused by damage to the structural components of the bacterial cell membrane. Cell damage disrupts nutrient transport (compounds or ions) through cells so that bacterial cells lack the nutrients needed for growth (Sari and Mursiti, 2016). Tannins also have a target on cell wall polypeptides so that the formation of cell walls is less than perfect. This causes the bacterial cell to lyse due to osmotic and physical pressure so that the bacterial cell will die. Terpenoid compounds have a mechanism of action as antibacterial substances allegedly involving membrane damage by lipophilic compounds. Terpenoids can react with porins (transmembrane proteins) on the outer membrane of the bacterial cell wall, forming strong polymeric bonds and damaging the porin, reducing the permeability of the bacterial cell wall so that the bacterial cell lacks nutrients, inhibits bacterial growth, or dies (Haryati et al., 2015)

Factors that affect the inhibition zone's size in bacteria are growth sensitivity, the reaction between the active ingredient and the medium and incubation temperature, environmental $\mathrm{pH}$, media components, colony density, incubation time, and microorganisms' metabolic activity. Another factor affecting the clear zone's size is the amount of active substance in the solution (Surjowardojo et al., 2016).

Table 4. Results of M. oliefera leaf extract disc test in 48 hours.

\begin{tabular}{|c|c|c|}
\hline $\begin{array}{l}\text { Concentration } \\
(\mathrm{mg} / \mathrm{L})\end{array}$ & $\begin{array}{l}\text { Average Inhibition } \\
\text { Diameter }(\mathrm{mm})\end{array}$ & $\begin{array}{l}\text { Inhibition Zone Response } \\
\text { Qualifications }\end{array}$ \\
\hline $\mathrm{K}-$ & $0 \pm 0,00^{\mathrm{a}}$ & Weak \\
\hline 75 & $4,48 \pm 0,57^{b}$ & Moderate \\
\hline 150 & $5,25 \pm 0,47^{\mathrm{bc}}$ & Moderate \\
\hline 225 & $6,42 \pm 1,37^{\text {cd }}$ & Moderate \\
\hline 300 & $6,56 \pm 0,93^{\text {cd }}$ & Moderate \\
\hline 375 & $7,07 \pm 0,62^{\mathrm{d}}$ & Strong \\
\hline $\mathrm{K}+$ & $16,23 \pm 0,53^{\mathrm{e}}$ & Very Strong \\
\hline
\end{tabular}

The inhibition zone diameter measurement at all doses with a time interval of 48 hours has decreased is presented in Table 4. Only positive control
(+) increased to $22.87 \mathrm{~mm}$. The decrease in inhibition zone diameter is due to antibacterial substances that only inhibit bacterial growth but do not wholly kill 
bacterial colonies (Kawengian et al., 2017).

According to Marfuah et al. (2018), Moringa leaf extract is bacteriostatic. The mechanism of action of antibacterial compounds is divided into two, namely bacteriostatic and bactericidal. If the antibacterial compound inhibits bacterial growth, it is included in the bacteriostatic group, whereas if it kills bacteria, it is included in the bactericidal group. The decrease in the inhibition zone size during the 48 hours incubation period can also be caused by several factors such as the nature of the bacteria itself and the compound's ability to suppress bacterial growth or the state of the active ingredient of the antibacterial compound used.

Table 5. The effectiveness of inhibition in 24 and 48 hours.

\begin{tabular}{ccc}
\hline Concentration & $\begin{array}{c}\text { Effectiveness of inhibition in } \\
24 \text { hours }\end{array}$ & $\begin{array}{c}\text { Effectiveness of inhibition } \\
\text { in 48 hours }\end{array}$ \\
\hline 75 & $32,5 \%$ & $28,2 \%$ \\
150 & $38,4 \%$ & $33,1 \%$ \\
225 & $44,6 \%$ & $36,5 \%$ \\
300 & $45,6 \%$ & $42,2 \%$ \\
375 & $58,8 \%$ & $48,1 \%$ \\
Average & $43,98 \%$ & $35,00 \%$ \\
Standard Deviation & 0,098 & 0,058 \\
\hline
\end{tabular}

Based on table 5 , the percentage of effectiveness of Moringa leaf extract, all doses decreased after 24 hours. The extract with a $375 \mathrm{mg} / \mathrm{L}$ concentration was the most effective dose with inhibitory effectiveness of $58.8 \%$ in 24 hours. In contrast, the decrease was only $48.1 \%$ after 48 hours. Simultaneously, the extract with a $75 \mathrm{mg} / \mathrm{L}$ concentration was the least effective dose with the effectiveness of inhibition of only $32.5 \%$ at 24 hours and $28.2 \%$ at 48 hours.

The effectiveness of the inhibition of Moringa leaf extract against E. tarda bacteria is caused by the content of bioactive compounds in Moringa leaf extract, which can damage the protein synthesis system, damage to the cell wall, which causes lysis resulting in cell wall damage that can interfere with the mechanism of bacterial cell wall synthesis (Hamzah, 2019). This result is supported by the statement of Roslizawaty et al. (2013) that the substance's concentration influences an antibacterial substance's effectiveness. Increasing the concentration of substances causes an increase in the content of active compounds that function as antibacterial so that their ability to kill bacteria is also more remarkable. Nemeth et al. (2015) stated bacteriostatic antibiotics are assumed to require phagocytic cells to clear bacteria and are therefore considered less effective without an efficient immune response. This theoretical model has resulted in the recommendation that severely ill and immunosuppressed patients with bacterial infections should be treated with bactericidal antibiotics.

\section{Scanning Electron Microscope (SEM)}

The SEM results show the effect of treatment on changes in the bacterial cell structure which is presented in Figure 1. 

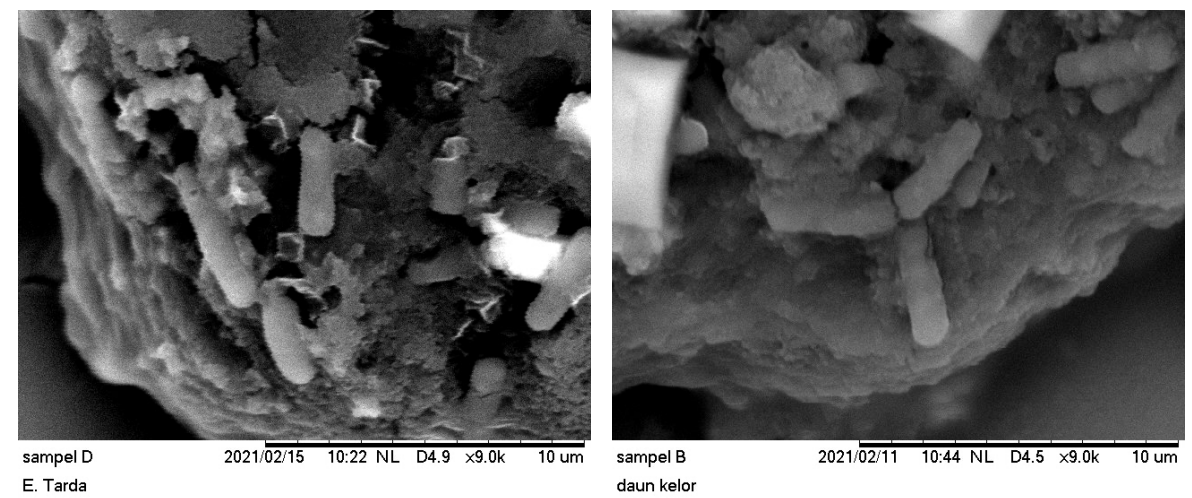

Figure 1. Summary of estimated growth parameters for C. gariepinus.

Figure A shows the morphology of $E$. tarda bacteria without any cell wall damage, while Figure $B$ shows the morphology of $E$. tarda bacteria that undergoes lysis due to cell wall instability that disrupts bacterial metabolism. This is due to the effect of giving Moringa leaf extract which has antibacterial active compounds, such as flavonoids, alkaloids, tannins, and terpenoids.

Inhibition of bacterial growth from alkaloid antimicrobial substances by inhibiting enzymes that play a role in the DNA replication process. Inhibition of DNA replication will cause bacteria to not be able to divide so that it inhibits bacterial growth. Meanwhile, the alkaloids contained in the extract can interfere with the formation of cross-bridges of peptidoglycan constituent components in bacterial cells, so that the cell wall layer is not fully formed and causes certain cell death (Ernawati and Sari, 2015). Flavonoids work as antibacterial with some mechanism of action, including inhibiting nucleic acid synthesis, inhibiting cytoplasmic membrane function, and inhibit the energy metabolism of bacteria (Manik et al., 2014). According to Ngajow et al. (2013), Tannins have antibacterial activity related to their ability to inactivate microbial cell adhesion and inactivate enzymes and interfere with protein transport in the inner layer of cells.

\section{CONCLUSION}

After conducting the research, several conclusions were obtained: the bioactive extract of Moringa leaves ( $M$. oliefera) is bacteriostatic as indicated by a reduction in the clear zone diameter after 48 hours of incubation. Besides, it was found that the effectiveness of Moringa (M. oliefera) leaf extract at a concentration of $375 \mathrm{mg} / \mathrm{L}$ against $E$. tarda bacteria and seen from the analysis of scanning electron microscopy, there was damage to E. tarda bacteria exposed to Moringa leaf extract.

\section{ACKNOWLEDGMENT}

We thank Brawijaya University and all parties who have aided in the completion of this research.

\section{REFERENCES}

A'yunin, Q., Kartikaningsih, H., Andayani, S. and Arifin, N.B., 2019. Efikasi Oxytetracycline Terhadap Kesehatan Ikan Lele yang Diinfeksi Bakteri Edwardsiella tarda. JFMR (Journal of Fisheries and Marine Research), 3(1), pp.105-110. http://dx.doi.org/10.21776/ub.jfm r.2019.003.01.15.

Alegantina, S., Isnawati, A. and Widowati, L., 2013. Kualitas ekstrak etanol $70 \%$ daun kelor (Moringa oleifera Lamk) dalam ramuan penambah ASI. Jurnal Kefarmasian Indonesia, 3(1), pp.1-8. https://ejournal2.litba

ng.kemkes.go.id/index.php/jki/arti cle/view/2862

Ashari, C., Tumbol, R.A. and Kolopita, M.E.F., 2014. Diagnosa penyakit bakterial pada ikan nila (Oreocrhomis niloticus) yang 
dibudidaya pada jaring tancap Di Danau Tondano. Budidaya Perairan, 2(3), pp.24-30. https://doi.org/10. 35800/bdp.2.3.2014.5700.

Ernawati and Sari, K., 2015. Kandungan senyawa kimia dan aktivitas antibakteri ekstrak kulit buah alpukat (Persea americana P.Mill) terhadap bakteri Vibrio alginolyticus. Jurnal Kajian Veteriner, 3(2), pp.203-211. https://doi.org/10.355 08/jkv.v3i2.1043

Fitriana, Y.A.N., Fatimah, V.A.N. and Fitri, A.S., 2019. Aktivitas anti bakteri daun sirih: uji ekstrak KHM (Kadar Hambat Minimum) dan KBM (Kadar Bakterisidal Minimum). Sainteks, 16(2), pp.101-108. https://doi.org/ 10.30595/st.v16i2.7126

Hamzah, A., 2019. Analisis in vitro aktivitas antibakteri daun sisik naga (Drymoglossum pilosellaoides) terhadap bakteri Vibrio harveyi dan Vibrio parahaemolyticus. Journal of Aquaculture and Fish Health, 8(2), pp.88-91. http://dx.doi.org/10.204 73/jafh.v8i2.11984.

Hariati, S., Wahjuningrum, D., Yuhana, M., Tarman, K., Effendi, I. and Saputra, F., 2018. Aktivitas antibakteri ekstrak kapang laut Nodulisporium sp. KT29 terhadap Vibrio harveyi. JPHP, 21(2), pp.250257. https://doi.org/10.17844/jph pi.v21i2.22855

Haryati, N.A., Saleh, C. and Erwin, 2015. Uji toksisitas dan aktivitas antibakteri ekstrak daun merah tanaman pucuk merah (Syzygium myrtifolium Walp.) terhadap bakteri Staphylococcus aureus dan Escherichia coli. Jurnal Kimia Mulawarman, 13(1), pp.35-40. http: //jurnal.kimia.fmipa.unmul.ac.id/i ndex.php/JKM/article/view/43

Hayati, Z., Yulia, W., Karmil, T.F. and Azmy, A., 2012. Anti-bacterial activity of rosella flowers extract (Hibiscus sabdariffa linn) in inhibiting bacterial growth methicillin-resistant Staphylococcus aureus. Proceedings of The 2nd Annual International Conference Syiah Kuala University 2012 \& The 8th IMT-GT Uninet Biosciences Conference, 2(1), pp.416-420. http:/ /jurnal.unsyiah.ac.id/AICS-SciEng/ article/view/1815/1712

Indriasari, Dewantoro, E. and Prasetio, E., 2020. Identification of the bacteria Edwardsiella tarda that infects catfish (Clarias batrachus) on several farmers in Sungai Raya District Kubu Raya Regency. Jurnal Borneo Akuatika, 2(1), pp.30-38. http://dx.doi.org/10.29406/jba.v2i 1.1981

Kadlec, K., Duijkeren, E.V., Wagenaar, J.A. and Schwarz, S., 2011. Molecular basis of rifampicin resistance in methicillin-resistant Staphylococcus pseudintermedius isolates from dogs. Journal of Antimicrobial Chemotherapy, 66(6), pp.1236-1242.

https://doi.org/10.1093/jac/ dkr118

Kartikasari, D., Nurkhasanah, N. and Pramono, S., 2014. Karakterisasi Simplisia dan Ekstrak Etanol Daun Bertoni (Stevia rebaudiana) dari Tiga Tempat Tumbuh. Prosiding Seminar Nasional "Perkembangan Terbaru Pemanfaatan Herbal Sebagai Agen Preventif Pada Terapi Kanker". Jurnal Ilmu Farmasi dan Farmasi Klinik, pp.145-141. http://dx.doi.org/10.31942/jif fk.v0i0.1216

Kawengian, S.A.F., Wuisan, J. and Leman, M.A., 2017. Uji daya hambat ekstrak daun serai (Cymbopogon citratus L) terhadap pertumbuhan Streptococcus mutans. e-GiGi (eG), 5(1), pp.7-11. https://doi.org/10.3 5790/eg.5.1.2017.14736

Kenconojati, H. and Rukman, N.R., 2019. Daya hambat ekstrak daun kelor (Moringa oleifera) terhadap Aeromonas hydrophila: studi awal untuk pengobatan aeromoniasis. Journal of Aquaculture Science, 4(1), 
pp.12-20. https://doi.org/10.31093 /joas.v4i1.64

Manik, D.F., Hertiani, T. and Anshory, H., 2014. Analisis korelasi antara kadar flavonoid dengan aktivitas antibakteri ekstrak etanol dan fraksi-fraksi daun kersen (Muntingia calabura L.) terhadap Staphylococcus aureus. Khazanah, 6(2), pp.1-11. http://dx.doi.org/10.20885/khazan ah.vol6.iss2.art1

Maqsood, S., Samoon, M.H. and Singh, P., 2009. Immunomodulatory and growth promoting effect of dietary levamisole in Cyprinus carpio fingerlings against the challenge of Aeromonas hydrophila. Turkish Journal of Fisheries and Aquatic Sciences, 9(1), pp.111-120. https:// www.trjfas.org/abstract.php?id $=73$ 7

Marfuah, I., Dewi, E.N. and Rianingsih, L., 2018. Kajian potensi ekstrak anggur laut (Caulerpa racemosa) sebagai antibakteri terhadap bakteri Escherichia coli dan Staphylococcus aureus. Jurnal Pengolahan dan Bioteknologi Hasil Perikanan, 7(1), pp.7-14. https://ejournal3.undip.ac .id/index.php/jpbhp/article/view/2 0383

Narwiyani, S. and Kurniasih, 2011. Perbandingan patogenesitas, Edwardsiella tarda pada ikan mas koki (Charassius auratus) dan ikan celebes rainbow (Telmatherina celebensis). Jurnal Riset Akuakultur, 6(2), pp.291-301. http://dx.doi.org /10.15578/jra.6.2.2011.291-301

Nemeth, J., Oesch, G. and Kuster, S.P., 2015. Bacteriostatic versus bactericidal antibiotics for patients with serious bacterial infections: systematic review and metaanalysis. Journal of Antimicrobial Chemotherapy, 70(2), pp.382-395. https://doi.org/10.1093/jac/dku37 9

Ngajow, M., Abidjulu, J. and Kamu, V.S., 2013. Pengaruh antibakteri ekstrak kulit batang matoa (Pometia pinnata) terhadap bakteri
Staphylococcus aureus secara In Vitro. Jurnal MIPA, 2(2), pp.128132. https://doi.org/10.35799/jm. 2.2.2013.3121

Pandey, A., Pandey, R.D., Tripathi, P., Gupta, P.P., Haider, J., Bhatt, S. and Singh, A.V., 2012. Moringa oleifera Lam. Sahijan) - A Plant with a Plethora of Diverse Therapeutic Benefits: An Updated Retrospection. Medicinal and Aromatic Plants, 1(1), pp.1-8. http://dx.doi.org/10.4172/ map. 1000101

Putra, I.W.D.P., Dharmayudha, A.A.G.O. and Sudimartini, L.M., 2016. Identification of chemical compounds ethanol extract leaf moringa (Moringa oleifera L) in Bali. Indonesia Medicus Veterinus, 5(5), pp.464-473. https://ojs.unud.ac.id/ index.php/imv/article/view/27257

Roslizawaty, Ramadani, N.Y., Fakhrurrazi and Herrialfian, 2013. Aktivitas antibakterial ekstrak etanol dan rebusan sarang semut (Myrmecodia sp.) terhadap bakteri Escherichia coli. Jurnal Medika Veterinaria, 7(2), pp.91-94. https://doi.org/10.21157

/j.med.vet..v7i2.2938

Sari, S.N. and Mursiti, S., 2016. Isolasi flavonoid dari biji mahoni (Swietenia macrophylla, King) dan uji aktivitasnya sebagai antibakteri. Indonesian Journal of Chemical Science. 5(3), pp.178-183. https://doi.org/10.15294/ijcs.v5i3. 9278

Surjowardojo, P., Susilorini, T.E. and Benarivo, V., 2016. Daya hambat dekok kulit apel manalagi (Malus sylvestris Mill) terhadap pertumbuhan Escherichia coli dan Streptococcus agalactiae penyebab mastitis pada sapi perah. Ternak Tropika, 17(1), pp.11-21. https://do i.org/10.21776/ub.jtapro.2016.017 .01 .2

Susanty, Ridnugrah, N.A., Chaerrudin, A. and Yudistirani, S.A., 2019. Aktivitas antioksidan ekstrak daun kelor (Moringa oleifera) sebagai zat 
tambahan pembuatan moisturizer. Prosiding Seminar Nasional Sains dan Teknologi, pp.1-7. https://jurnal .umj.ac.id/index.php/semnastek/ar ticle/view/5197

Wardhani, A.K., Sudarno and Kusdarwati, R., 2018. Gambaran histopatologi kulit dan insang benih ikan lele (Clarias sp.) yang terinfeksi Saprolegnia sp. dan yang telah diobati dengan ekstrak daun sirih (Piper betle L.). Journal of Aquaculture and Fish Health, 7(1), pp.25-31. http://dx.doi.org/10.204 73/jafh.v7i1.11227

Widowati, I., Efiyati, S. and Wahyuningtyas, S., 2014. Uji aktivitas antibakteri ekstrak daun kelor (Moringa oleifera) terhadap bakteri pembusuk ikan segar (Pseudomonas aeruginosa). PELITAJurnal Penelitian Mahasiswa UNY, 9(1), pp.146-157. https://journal.u ny.ac.id/index.php/pelita/article/vi ew/4018 